\title{
Forest Response to the US 1990 Clean Air Act: The Southern Spruce-Fir Ecosystem
}

\section{Stephen A. Banks}

North Carolina State University, Raleigh, USA.

Email: sabanks13@gmail.com

Received November $20^{\text {th }}$, 2013; revised January $15^{\text {th }}$, 2014; accepted January $27^{\text {th }}$, 2014

Copyright (C) 2014 Stephen A. Banks. This is an open access article distributed under the Creative Commons Attribution License, which permits unrestricted use, distribution, and reproduction in any medium, provided the original work is properly cited. In accordance of the Creative Commons Attribution License all Copyrights (c) 2014 are reserved for SCIRP and the owner of the intellectual property Stephen A. Banks. All Copyright (C) 2014 are guarded by law and by SCIRP as a guardian.

\section{ABSTRACT}

The history of the Black Mountains in North Carolina and the southern Spruce-Fir ecosystem has been fraught with widespread forest decline since the mid 1960's. Balsam Woolly Adelgid attacks and acidic deposition were two of the most recognized causes of decline. Uncertainty arose about the future of these forests, and projections were made regarding the endangerment or extinction of the endemic Fraser fir ([Pursh] Poiret). This study analyzed data sets from a permanent plot network in the Black Mountains dating 1985, 2002, and 2012. Indications that the Fraser fir population is stabilizing from a "boom-bust" cycle of population growth and has entered the stem exclusion stage of forest stand development are evident. Fir live stem density increased more than $250 \%$ from 1985 to 2002, and then declined $40 \%$ by 2012 at the highest elevations in the forest. Overall, fir appeared to be more impacted on western facing slopes than eastern ones. The population of red spruce experienced a steady decrease in live stem counts, but an increase in live basal area through all years, and at all elevation classes (1675 $\mathrm{m}, 1830 \mathrm{~m}$, and $1980 \mathrm{~m}$ ), indicating a normal progression through stand development. Red spruce was also most negatively impacted on western facing slopes. Live stem density was significantly higher $(P<0.001)$ than eastern plots, but live basal area was similar between the two aspects. Atmospheric deposition concentrations of the four main acidic molecules at Mt. Mitchell all peaked in 1998, but decreased by 2012. These reductions, occurring shortly after tightened regulations in the 1990 amendments to the Clean Air Act may have potential implications for increased forest resilience.

\section{KEYWORDS}

Southern Spruce-Fir; Balsam Woolly Adelgid; Forest Stand Development; Forest Response; Forest Regeneration; Atmospheric Deposition; Forest Decline

\section{Introduction}

The Southern Appalachian Mountains of North Carolina, Virginia, and Tennessee house a unique and rare forest ecosystem type known as the Appalachian Spruce-Fir [1]. Canopy dominating tree species in these forests include the red spruce (Picearubens Sargent) and the endemic Fraser fir (Abiesfraseri [Pursh] Poiret). These historical forest ecosystems are remnants of the Pleistocene epoch in an era when the northern reaches of the forests were affixed to the Appalachian southern reaches [1-3]. Despite similar appearance and floristic continuity [4] to boreal spruce-fir forests extending from Alaska into eastern Canada, these southern montane spruce-fir forests differ in many aspects. Species composition differences exist in the Appalachian ranges where Picearubens dominates rather than Piceamariana or Piceaglauca, as in boreal systems. The endemic Fraser fir, Abiesfraseri, exists only in the southern Appalachian ranges, as opposed to Balsam fir, Abiesbalsamea, in the boreal reaches [5]. Additionally, a deciduous shrub understory consisting of Rhododendron catawbiense exists in the Appalachian spruce-fir forest [1,6], whereas boreal forests are essentially one-storied with few shrub species [7].

Interest for the southern spruce-fir forests peaked after the exotic balsam woolly adelgid, Adelgespiceae, (BWA) was discovered at Mt. Mitchell, NC in 1957 on 12 Fraser 
fir trees [8]. BWA induced damage and fir rotholz (abnormal wood) production increased at Mt. Mitchell from the 1960's through to the late 1980's [9]. Extensive research was conducted during these years to determine the impacts BWA would have on the unique ecosystem of these relic forests. Large population losses of Fraser fir as high as $91 \%$ in the Great Smoky Mountains, NC (GSM), $61 \%$ in the Black Mountains, NC, and $44 \%$ at Roan Mountain, NC/TN were reported [10,11]. This level of disturbance however was classified as "minor", since not all existing trees were killed [12]. Major disturbances exist when all trees are removed above the forest floor vegetation. This level of differentiation was difficult for the Black Mountains since mortality of Fraser fir reached $100 \%$ at some elevations and less than $20 \%$ in others [10]. Estimates from 1986 by Nicholas et al., [13] indicated stand basal areas of live fir in the Great Smoky Mountains to be $8 \%-62 \%$ of that measured in 1946 by Oosting and Billings (1951). These declines were largely attributed to BWA infestation [14,15], but many other factors may have played a prominent role in increasing the damage. Secondary impacts occurred as red spruce started showing signs of damage and decline in the Southern Appalachians [16-18].

Atmospheric deposition and climate change are suggested to have had a large amplifying role in forest decline and mortality [19-22]. Cloud climatology indicates that Mt. Mitchell is exposed to 2 to 8 hour cloud episodes 258 days of the year on average [23]. The accumulation of acidic substances by the forest was of great concern as many studies showed elevated levels of ionic deposition especially by way of cloud droplets [23,24]. The most prevalent chemical components of cloud water collected at Mt. Mitchell were $\mathrm{H}^{+}, \mathrm{NH}_{4}^{2-}, \mathrm{SO}_{4}^{2-}$, and $\mathrm{NO}_{3}^{-}$ $[23,24]$. The concentration ratio of $\mathrm{SO}_{4}^{2-}$ to $\mathrm{NO}_{3}^{-}$in cloud water at Mt. Mitchell was significantly higher than levels measured in Los Angeles [24]. This deposition was thought to have direct forest health impacts, cause prolonged environmental degredation, and increase susceptibility of high elevation Fraser fir to BWA-caused mortality [19,23-25].

As BWA completed its attack on the Black Mountains, the forest contained large densities of dead standing stems. Researchers Bruck and Robarge reported the physical structure and integrity of the forest to be greatly deteriorated with many of the measured stands losing more than $50 \%$ of live Fraser fir stems [26]. Much of the forest experienced minor disturbances as not all stems had been removed, but some severely impacted areas of the forest experienced major, or stand replacing disturbances. These disturbances changed the forests stand dynamics, shifting the impacted areas into the stand initiation stage [12]. The stand initiation stage is characterrized by many numbers of species competing for grow- ing space in areas where space had been made available by way of disturbance. Bowers [27] found significantly more live stems at higher elevations than had been recorded previously in 1985; evidence of high stem recruitment and competition.

Although no decisive conclusion was reached regarding exact causality of the recorded declines, many researchers projected that large scale forest changes were inevitable. Some predictions indicated that widespread mortality of both spruce and fir was plausible, resulting in long term successional changes involving species replacements by more tolerant species [28]. Others suggested that post decline Fraser fir seedling recruitment was exceptionally high, and stems were likely to reach cone bearing age within 5 - 10 years. In this scenario it was estimated that Fir would reestablish itself within the Mt. Mitchell forest community [29]. A twenty year projection of forest growth was created from data gathered in 1986 from various regions in the southern Appalachians, including the Black Mountains where the current study is located [30]. Nicholas [30] projected red spruce declines in the Black Mountains for live basal area, and live stem density at every elevation range by 2009. Similar projections were also made for the yellow birch population, with exception of the lower elevation classes. Fraser fir however was projected to increase in live basal area at most elevations, and experience rapid declines in live stem density. Balsam woolly adelgid resurgence within 35 - 60 years for the Southern Appalachians was also predicted as maturing stems grew into susceptible size [31]. Smith and Nicholas [32] suggested a cycle of fir regeneration and BWA induced mortality would occur, possibly even sooner than Eager's [31] estimated 35 - 60 years.

The current study was conducted on the same set of plots measured by Nicholas [30] and Bowers [27] in the Black Mountains and falls just four years outside of the 20-year prediction range Nicholas [30] estimated. The study objectives were to 1) examine changes in stand dynamics by quantifying forest composition, growth, death, and succession based on analysis of live/dead basal area, live/dead stem densities, and diameter at breast height (DBH) 2) compare the results of this analysis to the projections made about growth/declines in the Black Mountain forest community and 3) determine changes in key chemical constituents attributed to forest decline over the past 27 years.

\section{Materials and Methods}

A network of 40 permanent plots was established during 1985 and 1986 in the Black Mountains by Nicholas [30]. Each plot was categorized by elevation (1525, 1675, 1830, and $1980 \mathrm{~m} \pm 30 \mathrm{~m}$ ), topographic type (ridge/ slope/draw), exposure to prevailing winds (exposed vs. 
protected), and plot aspect (east or west facing). Plots were established as $20 \times 20 \mathrm{~m}^{2}$ projected quadrangles (0.04 ha [0.10 ac]), corrected for slope angle, and marked with PVC pipe in all four corners to establish plot boundaries. The a priori definition of a southern spruce-fir type required plots $20 \times 20 \mathrm{~m}^{2}$ ( $\left.0.04 \mathrm{ha}\right)$ had to have at least $25 \%$ live spruce and/or fir, or former (dead standing stems) comprising the canopy cover. Twenty eight of the original 40 plots were recovered and resurveyed by Bowers [27], and 19 were recovered in the current survey.

Additionally, sixteen one-hectare circular stands were established by Bruck \& Robarge [19] in 1984 and five of these were recovered in 2012. Each one-hectare stand contained three randomly located 30-meter long transects that oriented from stand center, and served as a sub-plot center line. A two-meter boundary on either side of the center line marked the sub-plot boundary. For the three sub-plots within the 1 hectare stand, the total surveyed area equaled 0.036 ha $(0.09 \mathrm{ac})$. Combining the VPI plot recovery with the Bruck-Robarge plot recovery, this study surveyed a total of 24 plots. Only one plot was recovered at the $1525 \mathrm{~m}$ elevation and was excluded from the analysis, leaving a total of 23 re-surveyed plots.

Information collected for the VPI plots included updated GPS points at the designated "starting points" that were often off a maintained trail, as well as points for all four corners of the $20 \times 20 \mathrm{~m}$ plots. For the 1984 BruckRobarge plots, GPS points were taken at stand center, and a point at the beginning and end all three $30 \mathrm{~m}$ transect. General information for both sets of plots included plot elevation collected by GPS, slope percent, aspect of plot face, a species list of predominant woody and herbaceous plants, a description of plot terrain, groundcover, images of canopy closure from approximately plot center, and general weather conditions.

All resurvey data collected were congruent with the measurements established by Nicholas [30]. Trees were identified by aluminum tags at the base and referenced to species lists provided by Bowers [27] to ensure accuracy. Resurveyed trees were measured at diameter at breast height $(\mathrm{DBH})$ to the nearest $\mathrm{mm}$, categorized for crown condition (Class 1: 100\% - 90\% leaves or needles intact; Class 2: $90 \%-50 \%$ intact; Class 3: $49 \%$ - 1\% intact, Class 4: standing dead). Crown classes were sorted into two categories: healthy and decline. Classes one and two were included in the healthy category while classes three and four were pooled into the decline category. Tree crowns were also subject to a position classification by Bowers [27] to determine their relative dominance in the stand. Additional visual inspections were performed on the bole and foliage of the individual trees for abnormalities such as BWA infestation, necrosis, cankers, etc.
All atmospheric deposition data were gathered from the National Atmospheric Deposition Programs (NADP) electronic database available for public use

(http://nadp.sws.uiuc.edu/). Data were collected for NADP's monitoring location NC45 which corresponded to a monitoring station atop Mt. Mitchell, NC at $1987 \mathrm{~m}$ in elevation.

\section{Statistical Analysis}

The assumptions of analysis of variance (ANOVA) were verified for all three data sets. Plot means for live and dead basal area as well as plot densities of live and dead stems were used as response variables in ANOVA. Year, elevation class, aspect, and all three two-way interactions were included as sources of variation. In cases where interactions were not significant, they were pooled into the error by rerunning a reduced model. Tukey-Kramer multiple comparison tests were used for all post hoc comparison of means. The crown class data was sorted into a binary distribution and analyzed using a generalized linear mixed model. Year, elevation class, aspect, and all three two-way interactions were again included as sources of variation. A log it link function was used to compute the log it transformation of the binary data. The least squared means output provided is reported on the back-transformed scale, and was converted to a percentage. All statistical procedures were performed using SAS 9.3 (SAS Institute Inc., Cary, North Carolina) and conducted at the $\alpha=0.10$ level.

All atmospheric deposition data were analyzed in Microsoft Excel using the reported means from the National Atmospheric Deposition Program. These data were analyzed under a general linear regression format and fit to a second order polynomial with the form:

$$
\hat{y}=b_{0}+b_{1} x+b_{2} x^{2}
$$

\section{Results}

This analysis reevaluated the effects that time (years), elevation, and aspect had upon a set of response variables, and attempts to build a congruent set of data for use in future long term analysis. The analysis determined responses in basal area, stem density, and stem size distributions for all species, as well as focusing on three most abundant species; Abiesfraseri, Picearubens, and Betulaalleghaniensis. The data contained in the "all species" category is viewed in this study as a representation of the forest community as a whole. Species pooled into the community category along with the three main species were, Acer spicatum, Prunuspennsylvanica, Rhododendron sp., and Sorbus Americana, which made up less than $15 \%$ of the stems in the surveyed population. The remaining portion of species totaled less than $4 \%$ of data, 
and included Acer pensylvanicum, Acer rubrum, Acer saccharum, Betula papyrifera, Ilex montana, Tsugacanadensis, Vaccinium $s p$, and an unknown category used when a dead stem couldn't be identified.

\subsection{All Species}

At the community level, no significant differences were observed in live basal area (LBA) among all years, elevations, or aspects (Table 1). No differences occurred in dead basal area (DBA) over time, however significant differences were found among the three elevations, including a 215\% increase from plots at $1675 \mathrm{~m}$ and those at $1980 \mathrm{~m}$. DBA and dead stem density (DSD) significantly increased in west facing plots for the community as a whole. West facing plots in the Black Mountains had significantly more $(P=0.05)$ DSD than those facing east with differences of 427.4 stems/ha in the east to 821.3 stems/ha in the west. Year was also a significant predictor for DSD (Table 1). A marked decline in DSD from 671.9 to 491.3 stems/ha from 1985 to 2002 represented a 26\% decrease over 17 years. However, current 2012 levels have increased from 2002 by $9 \%$ reaching 537.2 stems/ha. DSD for the forest community also was significantly different among elevations; where more DSD occured at $1980 \mathrm{~m}$ than at both lower elevations. At $1980 \mathrm{~m}$, Fraser fir was most abundant with a population that accounted for $83 \%$ of the stems at $1980 \mathrm{~m}$ and remained dominant until the $1675 \mathrm{~m}$ elevation class (Figure 1). Although the interaction between elevation and year was not a significant predictor of DSD, large differences occured at $1980 \mathrm{~m}$ among all three years. In 1985 at 1980 $\mathrm{m}$, DSD was 1406.3 stems/ha, decreasing in 2002 to 433.3 stems/ha, and in 2012 increased to 948.8 stems/ha.

Live stem density (LSD) within the community was significantly affected $(\mathrm{P}=0.02)$ by the interaction between year and elevation (Table 1). Significant increases occurred at $1980 \mathrm{~m}$ between 1985 and 2002, but 2012 LSD levels fell between the two (Table 2). This trend also occurred at the $1830 \mathrm{~m}$ elevation, although no significant differences occurred among the years. Live basal area for the community showed increases from 1985 to 2002 at the highest two elevation classes similar to LSD, however in 2012 LBA remained similar to the 2002 levels. At the lowest elevation (1675 m), LBA as well as LSD had decreased consistently from 1985 through 2012.

\subsection{Fraser Fir (Abiesfraseri)}

The Fraser fir population in the Black Mountains is highly dependent upon elevation as has been well documented for Fraser fir's native range. Across all 27 years, elevation was a highly significant predictor for live/dead basal area, and stem densities (Table 1). Fir LBA over
Table 1. Significant $(\mathbf{P}<\mathbf{0 . 1 0})$ effects of environmental variables year, elevation, aspect, and their interactions on live and dead basal area (LBA, DBA) and live and dead stem densities (LSD, DSD) by species. “-” indicates non-significance.

\begin{tabular}{|c|c|c|c|c|}
\hline Source & LBA & DBA & LSD & DSD \\
\hline \multicolumn{5}{|l|}{ All Species } \\
\hline year & - & - & 0.017 & 0.016 \\
\hline elevation & - & 0.000 & 0.004 & 0.001 \\
\hline aspect & - & 0.045 & - & 0.047 \\
\hline year*elevation & - & - & 0.016 & - \\
\hline \multicolumn{5}{|l|}{ Abiesfraseri } \\
\hline year & - & - & 0.011 & - \\
\hline elevation & 0.000 & 0.010 & 0.000 & 0.038 \\
\hline aspect & - & 0.085 & - & - \\
\hline year*elevation & - & - & 0.022 & - \\
\hline \multicolumn{5}{|l|}{ Picearubens } \\
\hline year & - & 0.071 & - & - \\
\hline elevation & 0.000 & 0.072 & 0.000 & - \\
\hline aspect & 0.092 & - & 0.069 & - \\
\hline year*elevation & - & 0.014 & & - \\
\hline elevation*aspect & 0.070 & - & 0.001 & - \\
\hline \multicolumn{5}{|c|}{ Betula alleghaniensis } \\
\hline elevation & 0.001 & - & 0.000 & - \\
\hline elevation*aspect & 0.011 & - & 0.009 & - \\
\hline
\end{tabular}

Table 2. Live stem density means and standard errors of the year and elevation interaction for all pooled species. Significant differences are assigned different superscripts $(\mathbf{P}=$ 0.05).

\begin{tabular}{cccc}
\hline & $1675 \mathrm{~m}$ & $1830 \mathrm{~m}$ & $1980 \mathrm{~m}$ \\
\hline 1985 & $1706 \pm 183$ & $1667 \pm 237$ & $1188^{\mathrm{a}} \pm 296$ \\
2002 & $1379 \pm 338$ & $1831 \pm 298$ & $4556^{\mathrm{b}} \pm 1111$ \\
2012 & $852 \pm 141$ & $1521 \pm 247$ & $2630^{\mathrm{ab}} \pm 1000$ \\
\hline
\end{tabular}

this time span averaged $0.9 \mathrm{~m}^{2} / \mathrm{ha}$ at $1675 \mathrm{~m}, 12.6 \mathrm{~m}^{2} / \mathrm{ha}$ at $1830 \mathrm{~m}$, and $27.5 \mathrm{~m}^{2} /$ ha at $1980 \mathrm{~m}$. When stratified by year, fir experienced increases in LBA from 1985-2002, which then declined in 2012. Similarly, LSD was significantly affected $(\mathrm{P}=0.02)$ by the interaction between year and elevation. At $1980 \mathrm{~m}$, LSD significantly increased by 352\% from 1985 to 2002 (918.9 to 4156.3 stems/ha), then decreased in 2012 by $42 \%$ to 2374.3 stems/ha (Figure 2). LBA in 2012 however decreased only $9 \%$ from 33 to $29.9 \mathrm{~m}^{2} / \mathrm{ha}$.

This analysis determined that Fraser fir DBA in the Black Mountains was also highly dependent upon elevation and aspect (Table 1). On west facing slopes, fir had 

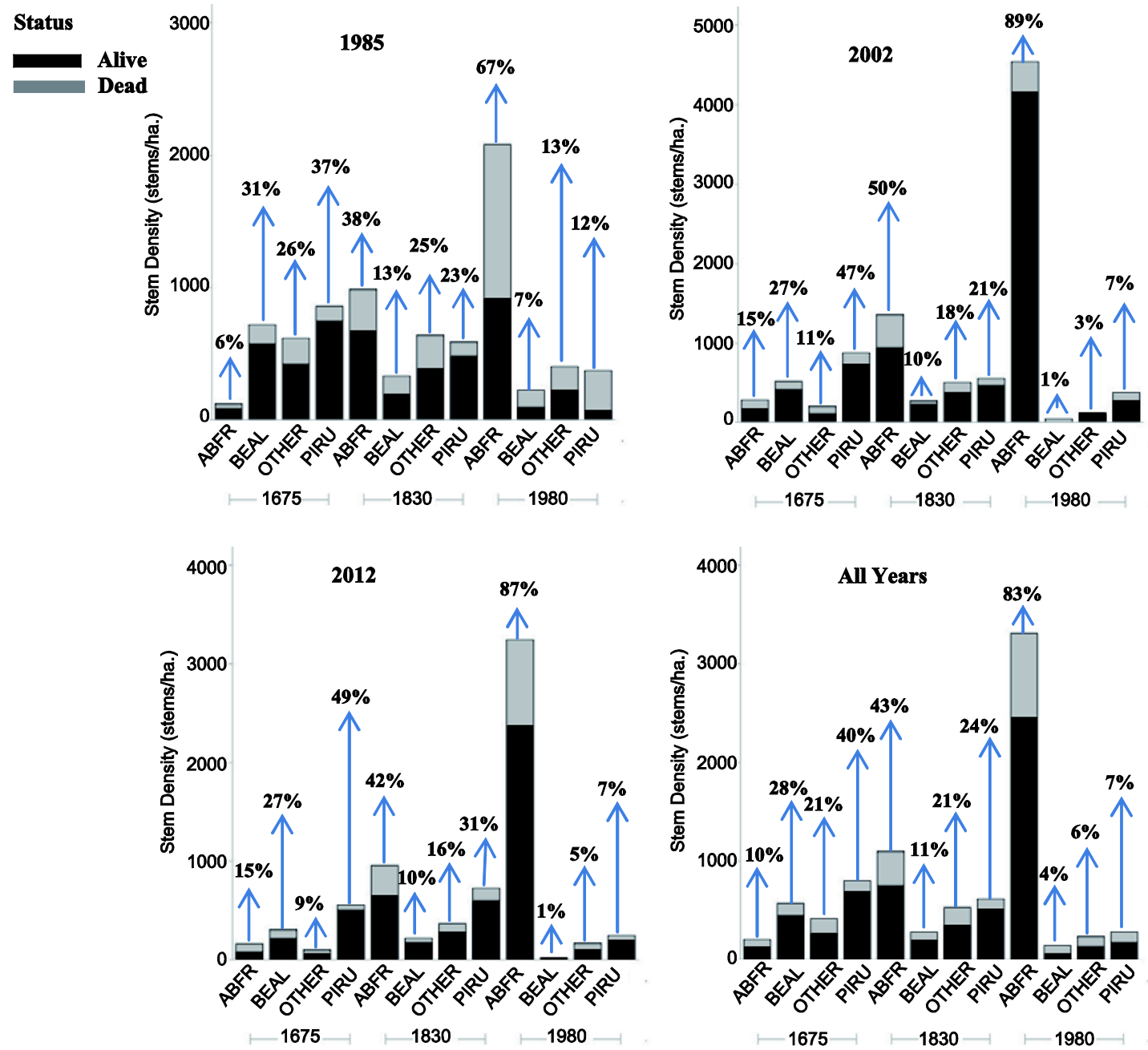

Figure 1. Stem counts per hectare with percent of species contained in each elevation class for all three datasets, and summation of combined data across 27 years. Arrows point to species percentage amount. Percentages are based on total combined live and dead stems within each elevation class. Bars are separated to give perspective on changes in live and dead stems over the years. ABFR-fraser fir, BEAL-yellow birch, PIRU-red spruce.

a significantly higher DBA than on eastern slopes, with an average difference of $10.3 \mathrm{~m}^{2} / \mathrm{ha}$ among the aspects (Figure 3). At elevation $1830 \mathrm{~m}$, DSD and DBA show a "boom and bust" trend from 1985, 2002, and then 2012. At 1980 m fir DSD decreased from 1985-2002, then increased in 2012. Fraser fir diameter distribution for elevation class $1980 \mathrm{~m}$ in the Black mountains revealed trends that explain differences in stem densities and basal area (Figure 4). The largest observed differences can been seen in the diameter at breast height (DBH) distribution of dead Fraser fir at $1980 \mathrm{~m}$ in 2002. The median DBH among dead stems was $20.9 \mathrm{~cm}$ in 2002 as compared to $12.0 \mathrm{~cm}$ in 1985, and $12.7 \mathrm{~cm}$ in 2012. Similarly, live DBH class distribution in 2002 revealed a positively skewed distribution value of 3.4, with $95 \%$ of live stems below $17.0 \mathrm{~cm}$. In 1985, skewedness measured 1.6 with 95\% of live stems below $34.6 \mathrm{~cm}$, and in 2012 skewedness was 2.4 , with $95 \%$ of live stems below $21 \mathrm{~cm}$.

\subsection{Red Spruce (Picearubens)}

The red spruce population in the Black Mountains was mainly concentrated at the 1675 and 1830 meter elevation range. Differences in abundance and size of live stems are influenced mainly by what aspect the stand was facing, and at what elevation the spruce were growing (Table 1). Significant differences occured for both LBA $(P=0.07)$ and LSD $(P=0.00)$ based upon the interaction between elevation and plot aspect. At $1675 \mathrm{~m}$, LBA was very similar among the two aspects, but LSD exhibits a significantly higher number of live stems on western slopes (Figure 5). On western facing slopes, red spruce at $1830 \mathrm{~m}$ had significantly lower LSD and LBA than those at $1675 \mathrm{~m}$, despite having a similar overall stem count between the two elevations (Figure 1). At $1830 \mathrm{~m}$ red spruce on western facing slopes had very low LBA values and was significantly lower than LBA on eastern 




Figure 2. Live stem density of Fraser fir at $1980 \mathrm{~m}$. A Tukey-Kramer multiple comparison analysis showed a statistically significant difference among LSD means between 1985 and 2002, as well as 1985 and 2012.

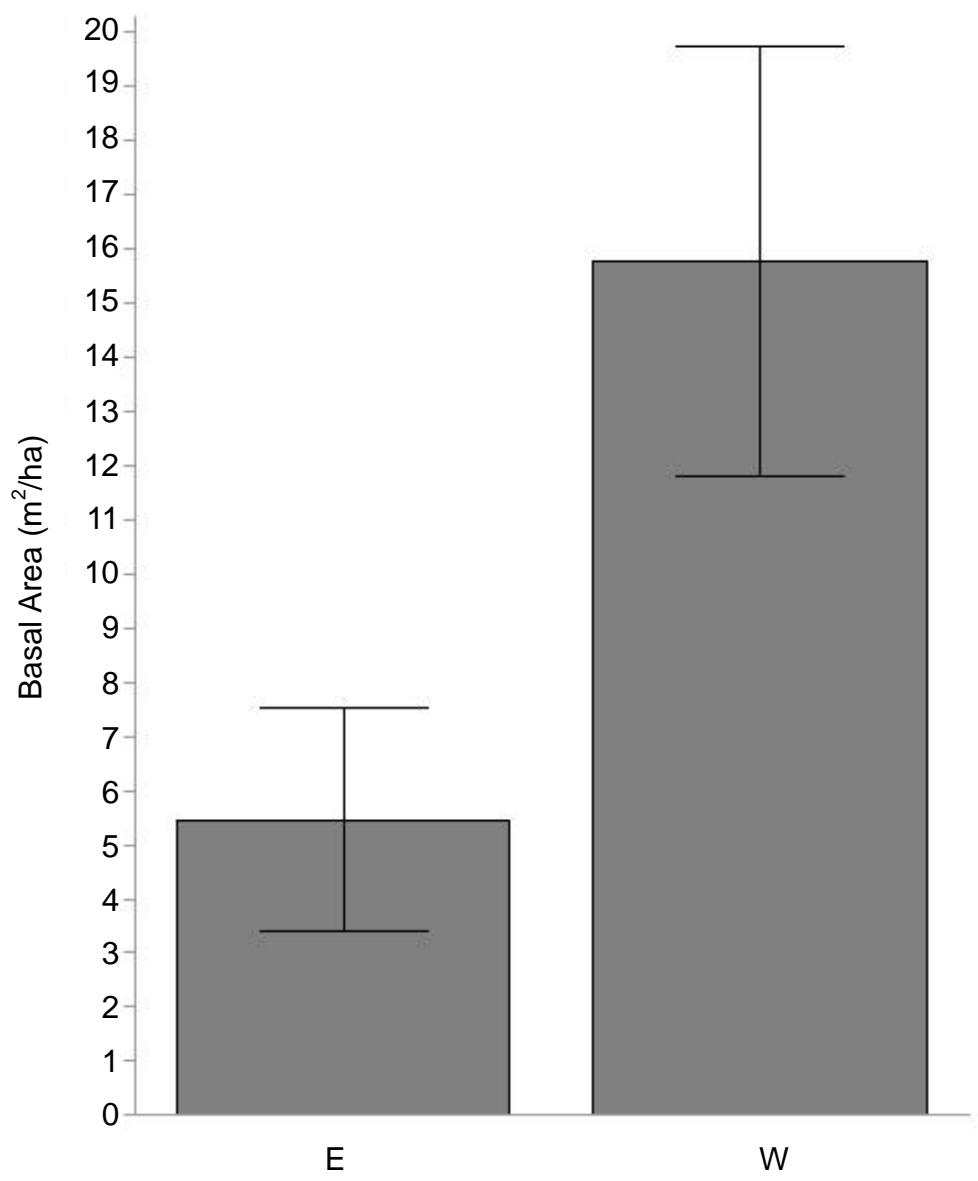

Figure 3. Fraser fir dead basal area differences between east (E) and west $(W)$ facing slopes. A Tukey-Kramer analysis reveals significantly higher DBA in western facing slopes. Data here is averaged among all years and elevations. 


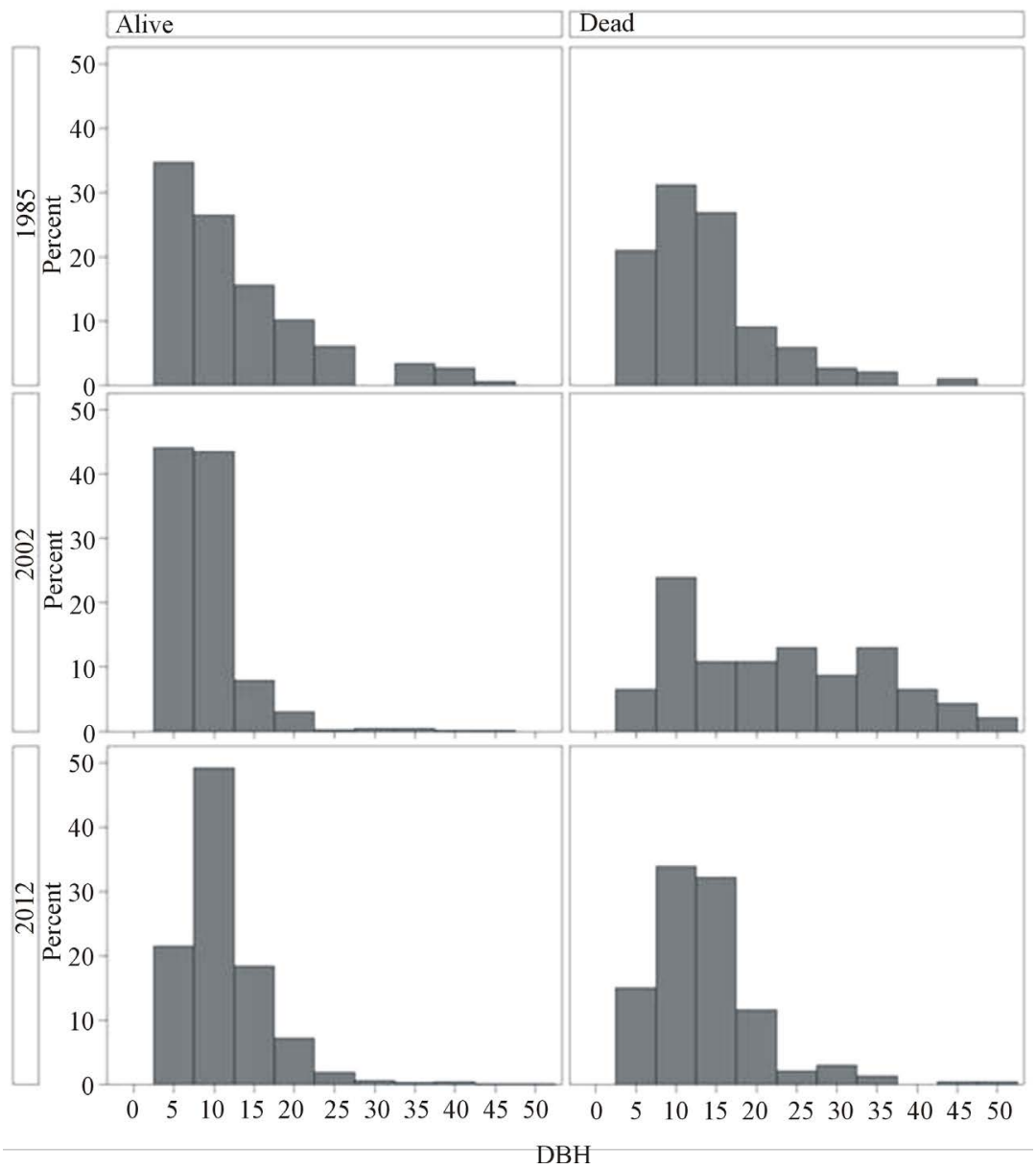

Figure 4. DBH size class distribution for live and dead Fraser Fir at $1980 \mathrm{~m}$ for each year strata.

slopes. With a low LBA of $5.4 \mathrm{~m}^{2} / \mathrm{ha}$ and LSD of 365.9 stems/ha, many red spruce stems on western slopes at $1830 \mathrm{~m}$ were likely to be small in diameter, indicating areas of stand initiation. In 2012, the distribution of red spruce DBA was reduced to $1.7 \mathrm{~m}^{2} / \mathrm{ha}$ from the previous 2002 DBA of $5.6 \mathrm{~m}^{2} / \mathrm{ha}$, representing a $69 \%$ decrease. The significant interaction in DBA between years and elevation $(P=0.01)$ was attributed to averages at $1980 \mathrm{~m}$; however there was low representation at this elevation and the level of significance may have been falsely representative. Differences did exist however at the lowest elevation $(1675 \mathrm{~m})$; DBA increased in years 1985 to 2002 from 2.6 to $7.4 \mathrm{~m}^{2} / \mathrm{ha}$, and then decreased to 2.4 $\mathrm{m}^{2} /$ ha in 2012. At $1830 \mathrm{~m}$, DBA continued to decrease from 1985 at 5.2 to $1.7 \mathrm{~m}^{2} /$ ha in 2012. Although no significant differences occurred, the trend was similar when examining Red Spruce DSD at 1675 m. At 1830 m, DSD decreased in 2002 from 1985 (108 to 91 stems/ha), but then increased in 2012 (125 stems/ha).

\subsection{Yellow Birch (Betula alleghaniensis)}

The yellow birch population in the Black Mountains ex- hibits similar results as the red spruce population. Yellow birch very rarely occurs at the highest elevation, with only two observations in the eastern plots while none occurred in the western plots for all survey years. Like red spruce, yellow birch LBA and LSD are significantly affected by the interaction between elevation and aspect. At $1675 \mathrm{~m}$ where it's most abundant (Figure 1), yellow birch showed significantly higher LSD values in west facing plots than eastern ones; Western plots averaged 602.8 stems/ha and eastern plots averaged 351.7 stems/ha (Figure 6). This trend is opposite that of the elevation and aspect interaction at $1830 \mathrm{~m}$. At this elevation (1830 $\mathrm{m})$, LSD as well as LBA was significantly higher in eastern plots. In west facing plots, yellow birch LSD and LBA was significantly higher at $1675 \mathrm{~m}$ than $1830 \mathrm{~m}$, but not in the eastern plots. Yellow birch DSD and DBA have remained relatively unchanged throughout the years. DSD slightly decreased over time from 139 stems/ha in 1985, 64.1 in 2002, to 56.3 stems/ha in 2012. No significant differences occurred for DSD or DBA across elevations or plot aspects. Between east and west facing slopes the DBA difference for all 27 years was only $0.42 \mathrm{~m}^{2} / \mathrm{ha}$ and the average DSD difference was only13.6 stems/ha. 


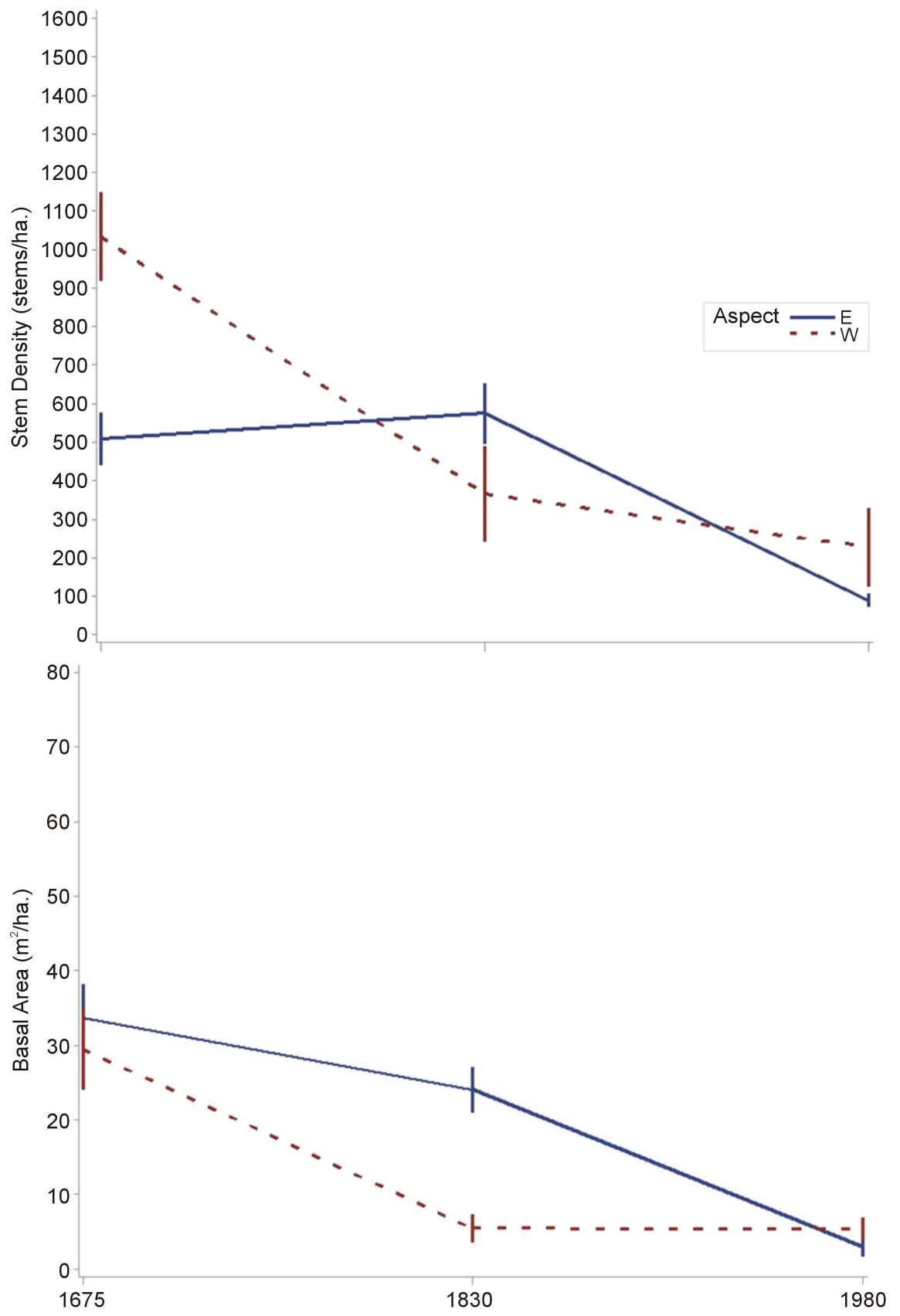

Figure 5. Comparison of the elevation and aspect interaction effect for Picearubens LSD and LBA with standard error bars. A Tukey-Kramer multiple comparison analysis reveals significant differences between aspects at 1675 m for LSD and at 1830 $m$ for $L B A$.

\subsection{Crown Classes}

The crown classes recorded for these data relate to the structural health of the forest. The community level analysis revealed that significant change had occurred at the highest elevation $(1980 \mathrm{~m})$. A significant increase in healthy stems occurred in 2002, but in 2012 had declined to a similar percentage of that found in the 1985 data. This observation is mirrored in the data for the Fraser fir and red spruce populations at $1980 \mathrm{~m}$ (Figure 7). Fraser fir at the $1830 \mathrm{~m}$ elevation range experienced significant increases in structural declines for each successive year analyzed (Figure 7). From 1985 to 2002 healthy fir significantly decreased by from $72.7 \%$ to $49 \%$ then decreased again by 2012 to only $37.6 \%$ healthy stems at the $1830 \mathrm{~m}$ elevation. The Fraser fir population also experienced significant declines in health at $1675 \mathrm{~m}$ when comparing structural health in 1985 to that of 2002 and 2012. In 1985, the percentage of healthy fir at $1675 \mathrm{~m}$ 

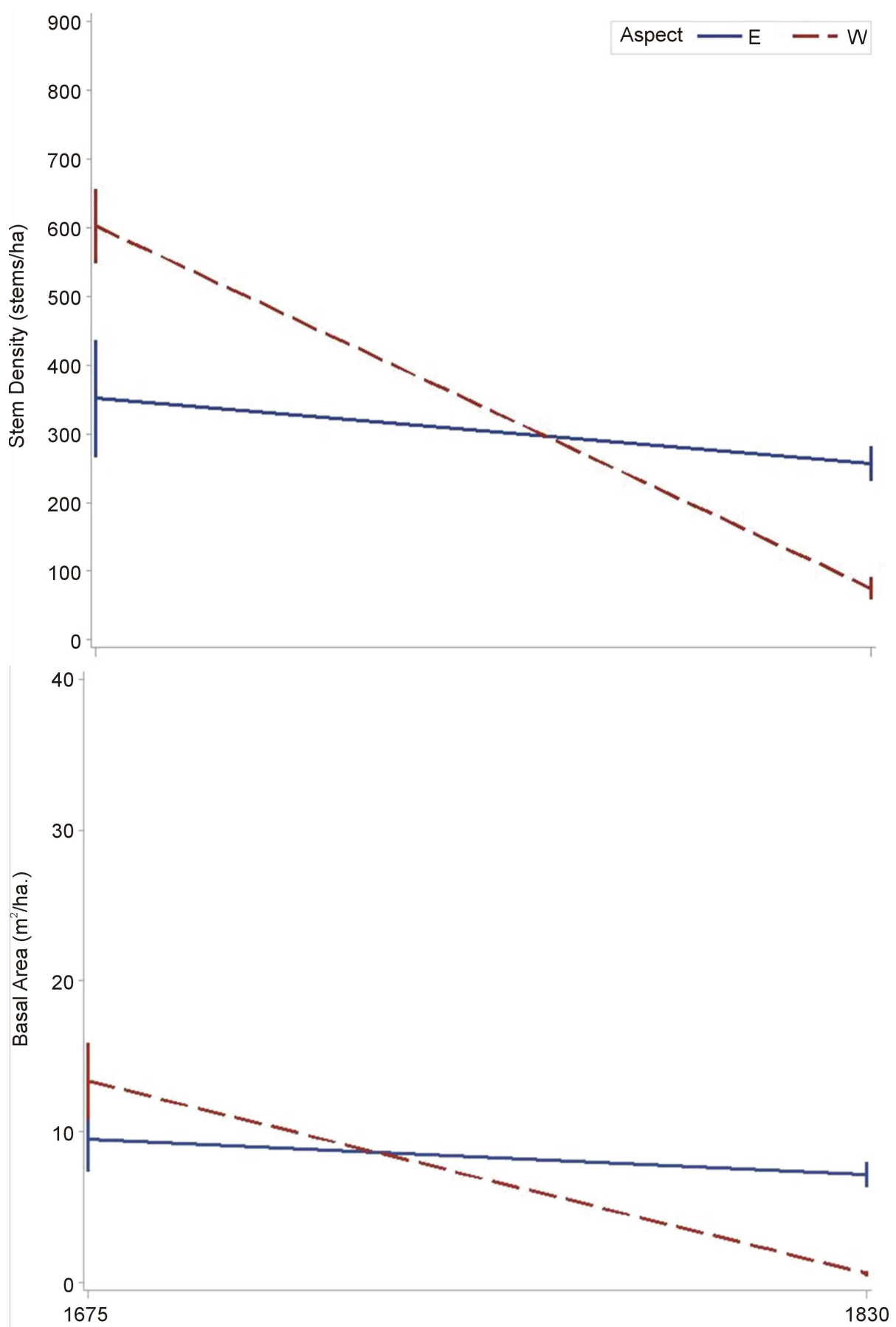

Figure 6. Comparison of the elevation and aspect interaction effect for Betula alleghaniensis LSD and LBA with standard error bars. Only two elevations are displayed due to low population densities at $1980 \mathbf{~ m}$. A Tukey-Kramer multiple comparison analysis revealed significant differences between aspects as well at between elevation for LSD and LBA.

was $88.8 \%$ but decreased to $66.1 \%$ in 2002 and $52 \%$ in 2012. The red spruce population significantly increased the amount of declining stems at the lowest elevation (1675 m) in 2002. Declining crown classes for red spruce in 1985 at $1675 \mathrm{~m}$ was only $10 \%$ then increased to $25 \%$ by 2002, but by 2012 the data revealed only 7\% were in decline.
The structural health of the Fraser fir population was also affected by what aspect the stand was facing. In western facing stands, Fraser fir was significantly less healthy than those on eastern slopes in 1985 and in 2002 (Figure 8). In 2012 however, the health had declined for both eastern and western facing stands, but no significant difference occurred among the aspects. 


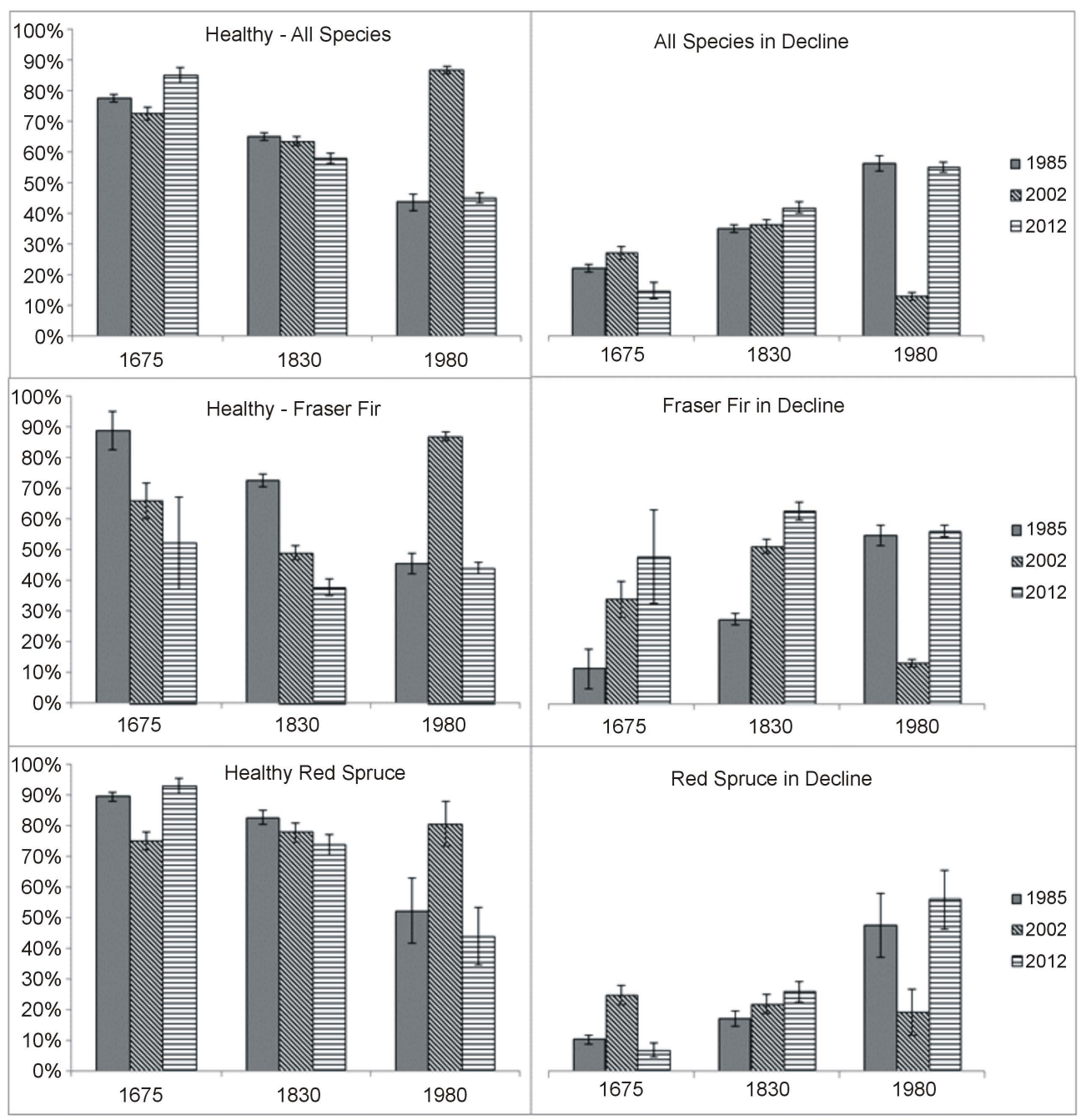

Figure 7. Changes in healthy and declining crown classes, by percent for all species in the community, Fraser fir, and red spruce at each elevation class throughout all years. Standard error bars are included for each of the observations and can be used to compare changes between years within each elevation class.



Figure 8. Aspect comparison of healthy crown classes for Fraser fir between each year of observation. Standard error bars are included for each mean. 


\subsection{Comparison of Current Forest Status to a 20-Year Projection}

Nicholas' [30] projections for 2009 were limited to estimations of LBA and LSD for the three most prevalent species in the forest, although some estimates of LSD were not reported. Predictions of red spruce and yellow birch LBA's were projected to decrease at every elevation class, with the exception of yellow birch at $1675 \mathrm{~m}$ which was projected to remain stable. The 2012 data show that rather than these projected decreases, LBA increased in every elevation class for both species (Table 3). Fraser fir LBA was predicted to increase at the lower two elevation classes and show stabilization at $1980 \mathrm{~m}$. The current 2012 data do not support this projection and show LBA at the lower elevation classes remained stable, but at $1980 \mathrm{~m}$ it more than doubled. LSD projections were provided for each species at every elevation class for 2009 (Table 4). Red spruce LSD for $1675 \mathrm{~m}$ was averaged with the estimate for a lower elevation class $(1525 \mathrm{~m})$ and resulted in a projected decrease to 573 stems/ha. The 2012 data shows this estimation to be relatively close to the $1675 \mathrm{~m}$ data at $508 \mathrm{stems} / \mathrm{ha}$. Yellow birch at this elevation was projected to have decreased to 151 stems/ha, but 2012 data indicated 223 stems/ha. The most prevalent differences in the projected and actual values were observed at the $1980 \mathrm{~m}$ elevation range. Nicholas (1992) projected that both red spruce and yellow birch would no longer exist at this elevation; both LBA and LSD for these species were projected to decline to zero. Both species still existed at this elevation in 2012, and red spruce showed the largest difference from the projections. Spruce LBA increased from 5.0 to $5.6 \mathrm{~m}^{2} / \mathrm{ha}$ with approximately 202 live stems/ha at the highest elevations in the Black Mountains.

\subsection{Atmospheric Deposition}

An analysis of the four most prevalent chemical components associated with atmospheric deposition at Mt. Mitchell show an increasing trend from 1986 to the late 1990 's, then all four experienced steady decreases through 2012 (Figure 9). The second order polynomial prediction equation generated for $\mathrm{H}^{+}$deposition explained $62.47 \%$ of the variation among years. $\mathrm{H}^{+}$deposition increased from 1986, peaking in 1998 at $0.56 \mathrm{~kg} / \mathrm{ha}$, then decreased by $69 \%$ by 2012 to $0.17 \mathrm{~kg} / \mathrm{ha}$. Like $\mathrm{H}^{+}$, concentrations of $\mathrm{SO}_{4}^{2-}$ deposition at Mt. Mitchell gradually increased from 1986 until peaking in 1998. $\mathrm{SO}_{4}^{2-}$ began decreasing shortly after 1998 and 2012 levels showed a $70 \%$ decrease from 28.44 to $8.4 \mathrm{~kg} / \mathrm{ha}$ respectively. $\mathrm{NO}_{3}^{-}$also reached maximum concentration in 1998 at $14.12 \mathrm{~kg} / \mathrm{ha}$ at Mt. Mitchell. By 2012 this level had decreased $49 \%$ to $7.12 \mathrm{~kg} / \mathrm{ha}$. The concentrations of $\mathrm{NH}_{4}^{+}$at Mt. Mitchell also experienced declines
Table 3. LBA comparison of Nicholas' (1992) 20-year projection for year 2009 and actual values recorded in 2012. LBA reported as $\mathrm{m}^{2} / \mathrm{ha}$. Arrows indicate projected increases or decreases from the measured 1989 LBA.

\begin{tabular}{ccccccc}
\hline & \multicolumn{2}{c}{$1675 \mathrm{~m}$} & \multicolumn{2}{c}{$1830 \mathrm{~m}$} & \multicolumn{2}{c}{$1980 \mathrm{~m}$} \\
\cline { 2 - 7 } & Projected & Actual & Projected & Actual & Projected & Actual \\
\hline $\begin{array}{c}\text { Red } \\
\text { Spruce }\end{array}$ & $\downarrow 26.3$ & 33.0 & $\downarrow 8.9$ & 25.9 & $\downarrow 0.0$ & 5.6 \\
$\begin{array}{c}\text { Fraser } \\
\text { Fir }\end{array}$ & $\uparrow 1.2$ & 0.4 & $\uparrow 22.9$ & 10.7 & $\leftrightarrow 12.5$ & 29.9 \\
$\begin{array}{c}\text { Yellow } \\
\text { Birch }\end{array}$ & $\leftrightarrow 8.1$ & 11.0 & $\downarrow 1.9$ & 6.3 & $\downarrow 0.0$ & 0.2 \\
\hline
\end{tabular}

Table 4. LSD comparison of Nicholas' (1992) 20-year projection for year 2009 and actual values recorded in 2012. LSD reported in stems/ha. Arrows indicate projected increases or decreases. Dashes indicate no available record.

\begin{tabular}{ccccccc}
\hline & \multicolumn{2}{c}{$1675 \mathrm{~m}$} & \multicolumn{2}{c}{$1830 \mathrm{~m}$} & \multicolumn{2}{c}{$1980 \mathrm{~m}$} \\
\cline { 2 - 7 } & Projected & Actual & Projected & Actual & Projected & Actual \\
\hline $\begin{array}{c}\text { Red } \\
\text { Spruce }\end{array}$ & $\downarrow 573$ & 508 & - & 603 & $\downarrow 0$ & 202 \\
$\begin{array}{c}\text { Fraser } \\
\text { Fir }\end{array}$ & - & 92 & $\downarrow 527$ & 653 & $\downarrow 295$ & 2374 \\
$\begin{array}{c}\text { Yellow } \\
\text { Birch }\end{array}$ & $\downarrow 151$ & 223 & - & 183 & $\downarrow 0$ & 25 \\
\hline
\end{tabular}

in concentrations over time, but were not as drastic as the other three. $\mathrm{NH}_{4}^{+}$decreased 34\% from 1998 to 2012, but overall has increased 159\% since 1986.

\section{Discussion}

The community level analysis for the Black Mountains over the past 27-year time span revealed a high quantity of DSD at the highest elevation (1980 m) in 1985. By 2002, significant increases in LSD at the 1980 m elevation range occurred. This dramatic increase in LSD was mainly attributed to Fraser fir as it comprised more than $80 \%$ of all stems at this elevation, and also showed significant increases in LSD by 2002. In 2012, the high LSD values decreased at $1980 \mathrm{~m}$ for the community as well as for Fraser fir, indicating onset of density-dependent mortality. Historic levels of LSD at the highest elevations within the Appalachian Spruce-Fir forests have shown fir LSD at $1920 \mathrm{~m}$ to be $1300 \mathrm{stems} / \mathrm{ha}$ [1]. Current levels of LSD at $1980 \mathrm{~m}$ are 2374 stems/ha, but have decreased from 4156 stems/ha in 2002. While LSD remains much higher in 2012 than Oosting and Billings [1] records, LBA is more similar. LBA in 2012 for Fraser fir at the highest elevation is $29.9 \mathrm{~m}^{2} / \mathrm{ha}$ and was 32.6 $\mathrm{m}^{2} /$ ha when Oosting and Billings [1] measured it in 1946. Size class distributions of the fir existing at this elevation range offer an explanation into these changes. The large shift in DBH size for live stems from 1985 to 2002 show that a tremendous amount of seedling recruitment 


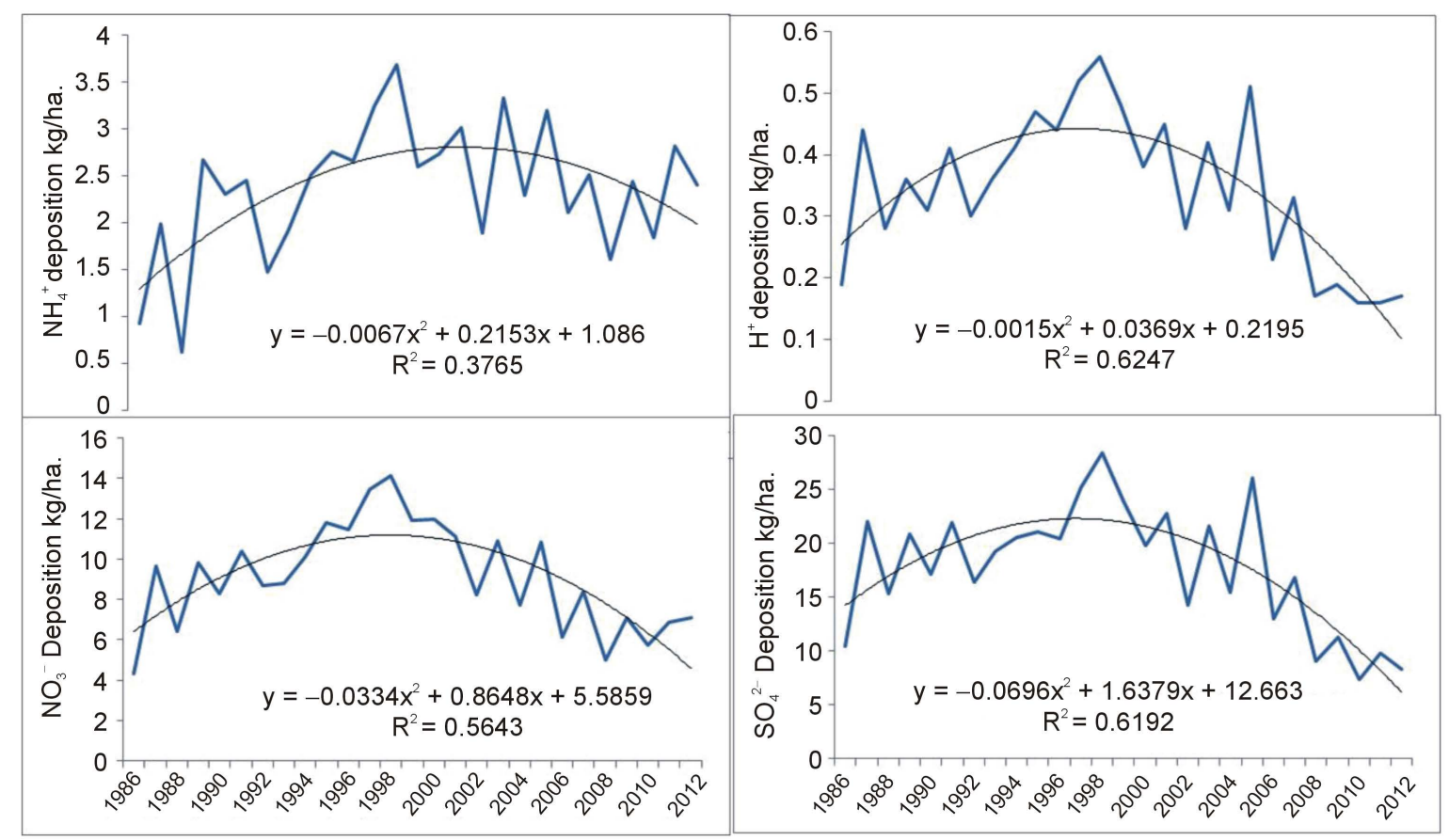

Figure 9. Concentrations of the four main atmospheric deposits attributed to forest decline measured at Mt. Mitchell State Park. Averages were fit to a second order polynomial regression equation. All four molecules have experienced declines in concentrations over time. Data Source: National Atmospheric Deposition Program.

occurred and average stem size is currently increasing and returning to the 1985 level (Figure 4). The increase in DSD and DBA for fir at $1980 \mathrm{~m}$ reaffirms that this high elevation forest is self-thinning which is characteristic of stands in the stem exclusion stage of stand dynamics. Additionally, Fraser fir DBA was found to be significantly higher on west facing plots. This result is consistent with the findings of [19]. This suggests more severe damage occurred on western slopes, and that eastern slopes may offer a more suitable growing environment. It is expected from this analysis that changes will continue to occur at the highest elevations in the Black Mountains. LBA averages may fluctuate within a 5 - 7 $\mathrm{m}^{2} /$ ha range, but seem to have reached a stable level. Based on the trend since 2002, LSD is predicted to continue to decrease over time. LSD is predicted to reach previously recorded, and assumed normal levels indicated by Oosting and Billings [1] within the next couple of decades. If these trends continue, a reduction in LSD will subsequently increase the amounts of DSD and coarse woody material on the forest floor.

The red spruce populations in the Black Mountains have rebounded from the declines that were reported after BWA induced fir mortality and decline events noted in the mid-2000's [33,27]. This study found differences in abundance and size of live stems to be influenced by stand aspect and elevation. On average, across all 27 years red spruce at $1675 \mathrm{~m}$ on west facing slopes was much more abundant, and had smaller diameter stems than those on eastern slopes. Similarly, at $1830 \mathrm{~m}$, the red spruce population contains smaller diameter stems, with significantly less LBA than eastern plots. Western facing slopes at these two elevations have been less favorable than eastern ones for Red Spruce over the past 27 years. However, overall averages for DBA, DSD, and LSD have decreased over time, while LBA increased from 1985-2002 and leveled off in 2012. This indicates that the red spruce population is not in decline, but is likely adjusting to the stem exclusion stage of stand development.

The yellow birch population is similar to the red spruce population with regards to which factors significantly influence differences in LBA and LSD. Yellow birch, like red spruce, experienced smaller stems overall in western facing plots than in eastern ones at the $1675 \mathrm{~m}$ elevation. At $1830 \mathrm{~m}$, eastern facing plots have significantly higher values of both LBA and LSD than those facing west, implying that a more favorable environment for yellow birch exists on eastern slopes.

The observed trends among the forest community, Fraser fir, and red spruce populations indicate a thinning effect in the higher elevations of the Black Mountains, where remaining stems are now moving into maturity and establishing canopy positions. In terms of stand dynamics, this observation represents the second stage of normal stand development after disturbance, known as the stem exclusion stage [12]. While it is understood that not all areas of a forest will uniformly be in the same 
developmental stage, some areas in the Black Mountains show similar patterns. Aspect and elevation may play a role in determining which stand development stage a particular area falls into at the Black Mountains. Western facing plots in the Black Mountains exhibit more abundant, smaller stems for both red spruce and yellow birch at the two elevation classes not entirely dominated by Fraser fir (1675 m and $1830 \mathrm{~m})$. Similarly, when averaged across all years and elevations, Fraser fir exhibited higher DBA on western facing slopes. This suggests that eastern facing slopes provide a more favorable environment for these species than western slopes. This trend could mean these areas have lower intensity of stand damaging events such as wind-throw or ice damage, or more favorable factors such as warmth, soil nutrients, soil water, etc.

Structural changes to the forest community in the Black Mountains occurred mainly at the highest elevation $(1980 \mathrm{~m})$. In 1985, declining stems at $1980 \mathrm{~m}$ reached close to $60 \%$, but by 2002 , with the influx of new stems, the percentage of those in good health was near 90\%. At 1980 m, both Fraser fir and red spruce experienced the same structural trends, further indicating a progression in the stand dynamics at the highest elevations. From 1985 to 2002 these high elevation areas had transitioned into the stand initiation stage of stand dynamics, and by 2012 the stands appeared to have moved into stem exclusion stage which helps explain the increased percentage of stems in decline. The high elevation Fraser fir population experienced a 20\% difference in healthy stems when comparing east and west facing slopes in 1985, with eastern facing slopes exhibiting near $80 \%$ healthy fir. In 2002, western facing plots were still significantly less healthy than those facing east. However, there was only an $11 \%$ difference between the two. By 2012, no significant difference existed among eastern and western facing slopes, but both exhibited high percentages of stems in decline. This self-thinning effect in 2012 is the essence of what occurs during the stem exclusion stage of stand dynamics.

Changes to LBA and LSD within the forest were largely not as projected by the 20 year projection model provided by Nicholas [30]. Red spruce and yellow birch was both projected to experience declines in LBA and LSD at all elevation classes. The 2012 data show that not only was there no declines, but large increases occurred in some parameters. It was estimated that the populations of these two species at $1980 \mathrm{~m}$ would be non-existent and the stand be solely dominated by fir. It appears based on these data that the projected analysis underestimated the degree of in growth that would occur after widespread Fraser fir mortality. Nicholas [30] estimated that Fraser fir LBA in the Black Mountains would increase in the lower elevations but remain stable at $12.5 \mathrm{~m}^{2} / \mathrm{ha}$ at
$1980 \mathrm{~m}$. The 2012 analysis showed distinctly opposite trends. The Fraser fir LBA remained relatively stable at the lower elevations (1675 m and $1830 \mathrm{~m}$ ) but dramatically increased by $131 \%$ at $1980 \mathrm{~m}$. These differences suggest that the original regression equation was unable to accurately predict changes in the Black Mountains.

The atmospheric deposition data presented here indicate an overall reduction of acidic deposition at Mt. Mitchell. All ionic constituents analyzed peaked in abundance from the late 1980's to the early-mid 1990's, then experienced reductions continuing through 2012. Soule found that radial growth of Red Spruce at Grandfather Mountain was negatively correlated with sulfur dioxides and nitrogen oxides [34]. This result supports the findings offered in the current study. The Black Mountains have experienced overall increases in LBA over the past 12 years, and have seen decreases in levels of acidic deposition during this time. This indicates that the forest around Mt. Mitchell is likely under much less environmental stress than was previously recorded when much of the forest was being affected by BWA. Bruck et al., (1988) found significantly higher levels of degraded stems at higher altitudes ( $>1800 \mathrm{~m})$ in the Black Mountains, and agreed with Schutt and Cowling (1985) that acidic deposition may be a predisposing or contributing factor to the degradation. Similar to the findings of Bruck et al. [19], the current study indicated the structure of crown classes in the Black Mountains were more severely affected at plots in the $1980 \mathrm{~m}$ elevation range. These changes showed a bimodal distribution with two distinct peaks of unhealthy stems. The 1985 and 2012 data showed higher levels of unhealthy stems than in the 2002 data. This reduction in unhealthy stems and subsequent increase in healthy stems in the 2002 data come shortly after the January 1, 2000 deadline for enhanced $\mathrm{SO}_{2}$ emission reductions set by the US Environmental Protection Agency. These reductions represented the second phase of Title IV-A of the 1990 amendments to the Clean Air Act, which included implementation of $\mathrm{SO}_{2}$ reduction technologies for an additional 2000 smaller power plants $(>75 \mathrm{MW})$ after the 110 larger ones $(\geq 100 \mathrm{MW})$ targeted in phase one [35]. The bimodal changes in forest structural health may have been driven by not only natural stand development, but also by the flux of emissions and resulting acidic depositions to the Black Mountains. Nonetheless, the reductions in acidic deposition suggests that the Black Mountains may be more resilient if another insect attack were to occur since pollutant stresses on individual trees are not as severe. Additionally, a finding of BWA in the Black Mountains was reported in 2008 with high populations especially at the lower elevations (1645 m - $1767 \mathrm{~m})$ [36]. Upon visiting the Black Mountains in 2009, McManamay did not observe any presence of BWA (McManamay, personal communication). The 
current 2012 study also found no indication of a BWA attack, suggesting potential improved forest defense or a short lived, low intensity, or small scale BWA attack.

\section{Concluding Remarks}

Based on the data presented here, the Southern SpruceFir forests of the Black Mountains have entered the stem exclusion stage of stand development and appear to be proceeding normally through stand development. The forest experienced a period of dramatic growth increase, especially at the highest elevations. Declines in live stem densities are now occurring, but these reductions do not appear to be abnormal, or caused by any other factor than direct competition. The forest has not yet reached previous live stem density levels recorded before BWA induced declines, but are close to approximately normal pre-disturbance levels of live basal area. It is predicted that within the next 40 - 60 years, given no BWA reoccurrence or other disturbance, the Spruce-Fir forest in the Black Mountains will resemble the forest as observed by Oosting and Billings [1] in 1946. If BWA resurgence or other disturbance were to occur, the forest community at Mt. Mitchell may be more resilient now, than at the time of the initial attack due to lower concentrations of acidic deposition to the forest community. Further research and monitoring are needed to address potential BWA re-occurrence in the Black Mountains. Furthermore, targeted studies should attempt to determine the effect acidic pollutants have regarding Fraser fir and the forest community's resilience to BWA attack.

\section{REFERENCES}

[1] H. Oostings and W. Billings, "A Comparison of Virgin Spruce-Fir Forest in the Northern and Southern Appalachian System,” Ecology, Vol. 32, 1951, pp. 84-103. http://dx.doi.org/10.2307/1930974

[2] S. A. Cain, "Pollen Analysis of Some Buried Soils, Spartanburg County, South Carolina,” Bulletin of the Torrey Botanical Club, 1944 pp. 11-22. http://dx.doi.org/10.2307/2481484

[3] M. F. Buell, "Late Pleistocene Forests of Southeastern North Carolina,” Torreya, Vol. 45, 1945, pp. 117-118.

[4] P. S. White, "The Upland Forest Vegetation of the Second College Grant, New Hampshire,” Ph.D. Dissertation, Dartmouth College, Hanover, 1976.

[5] C. V. Cogbill and P. S. White, "The Latitude-Elevation Relationship for Spruce-Fir Forest and Treeline along the Appalachian Mountain Chain,” Vegetatio, Vol. 94, No. 2, 1991, pp. 153-175. http://dx.doi.org/10.1007/BF00032629

[6] R. Whittaker, "Vegetation of the Great Smoky Mountains,” Ecological Monographs, Vol. 26, No. 1, 1956, pp. 1-80. http://dx.doi.org/10.2307/1943577

[7] G. H. La Roi, "Ecological Studies in the Boreal Spruce-
Fir Forests of the North American Taiga. I. Analysis of the Vascualr Flora," Ecological Monographs, Vol. 37, No. 3, 1967, pp. 229-253. http://dx.doi.org/10.2307/1948439

[8] C. F. Speers, "The Balsam Wooly Aphid in the Southeast," Journal of Forestry, Vol. 56, No. 7, 1958, pp. 515-516.

[9] R. G. Hollingsworth and F. P. Hain, "Balsam Woolly Adelgid Effects on Wood and Bark Structure of Fraser Fir and Silver Fir,” Environmental Entomology, Vol. 21, No. 5, 1992, pp. 1103-1109.

[10] C. W. Dull, "Evaluation of Spruce and Fir Mortality in the Southern Appalachian Mountains," Department of Agriculture, Forest Service (USFS), Southern Region, USA, 1988.

[11] G. F. Smith and N. S. Nicholas, "Patterns of Overstory Composition in the Fir and Fir-Spruce Forests of the Great Smoky Mountains after Balsam Woolly Adelgid Infestation,” American Midland Naturalist, Vol. 139, No. 2, 1998, pp. 340-352. http://dx.doi.org/10.1674/0003-0031(1998)139[0340:PO OCIT]2.0.CO;2

[12] C. D. Oliver, "Forest Development in North America Following Major Disturbances,” Forest Ecology and Management, Vol. 3, 1981, pp. 153-168.

[13] N. S. Nicholas, S. M. Zedaker and C. Eagar, "A Comparison of Overstory Community Structure in Three Southern Appalachian Spruce-Fir Forests,” Bulletin of the Torrey Botanical Club, Vol. 119, No. 3, 1992, pp. 316-332. http://dx.doi.org/10.2307/2996764

[14] L. Pitelka and R. Dudley, "Forest Decline and Acidic Deposition,” Ecology, Vol. 70, No. 1, 1989, pp. 2-10.

[15] J. M. Skelly, “A Closer Look at Forest Decline: A Need for More Accurate Diagnostics,” In: P. D. Manion and D. Lachance, Eds., Forest Decline Concepts, American Pathological Society Press, St. Paul, 1992, pp. 85-107.

[16] N. S. Nicholas and S. M. Zedaker, "Ice Damage in SpruceFir Forests of the Black Mountains, North Carolina," Canadian Journal of Forest Research, Vol. 19, No. 11, 1989, pp. 1487-1491. http://dx.doi.org/10.1139/x89-226

[17] R. T. Busing and E. F. Pauley, "Mortality Trends in a Southern Appalachian Red Spruce Population," Forest Ecology and Management, Vol. 64, No. 1, 1994, pp. 4145. http://dx.doi.org/10.1016/0378-1127(94)90125-2

[18] D. R. Peart, N. S. Nicholas, S. M. Zedaker, M. M. MillerWeeks and T. G. Siccama, "Condition and Recent Trends in High Elevation Red Spruce Populations,” In: C. Eager, and M. B. Adams, Eds., Ecology and Decline of Red Spruce in the Eastern United States, Springer-Verlag, New York, 1992, pp. 125-191.

[19] R. I. Bruck, W. P. Robarge and A. McDaniel, "Forest Decline in the Boreal Montane Ecosystems of the Southern Appalachian Mountains," Water, Air, and Soil Pollution, Vol. 48, No. 1, 1989, pp. 161-180.

[20] K. L. Webster, I. F. Creed, N. S. Nicholas and H. V. Miegroet, "Exploring Interactions between Pollutant Emissions and Climatic Variability in Growth of Red Spruce in the Great Smokey Mountains National Park," Water, Air, and Soil Pollution, Vol. 159, No. 1, 2004, pp. 225-248. http://dx.doi.org/10.1023/B:WATE.0000049179.26009.7f 
[21] P. T. Moore, H. V. Miegroet and N. S. Nicholas, "Relative Role of Understory and Overstory in Carbon and Nitrogen Cycling in a Southern Appalachian Spruce-Fir Forest," Canadian Journal of Forest Research, Vol. 37, No. 12, 2007, pp. 2689-2700. http://dx.doi.org/10.1139/X07-115

[22] K. A. Koo, B. C. Patten and I. F. Creed, "Picearubens Growth at High Versus Low Elevations in the Greast Smoky Mountains National Park: Evaluation by Systems Modeling," Canadian Journal of Forest Research, Vol. 41, No. 5, 2011, pp. 945-962. http://dx.doi.org/10.1139/x10-243

[23] V. K. Saxena, R. E. Stogner, A. H. Hendler, T. P. DeFelice and R. Y. Yeh, "Monitoring the Chemical Climate of the Mt. Mitchell State Park for Evaluation of Its Impact on Forest Decline,” Tellus, Vol. 41, No. 1, 1989, pp. 92109. http://dx.doi.org/10.1111/j.1600-0889.1989.tb00128.x

[24] D. S. Kim and V. P. Aneja, "Chemical Composition of Clouds at Mt. Mitchell, North Carolina, USA,” Tellus, Vol. 44, No. 1, 1992, pp. 41-53. http://dx.doi.org/10.1034/j.1600-0889.1992.00004.x

[25] F. P. Hain and F. H. Arthur, "The Role of Atmospheric Deposition in the Lattudinal Variation of Fraser Fir Mortality Caused by the Balsam Woolly Adelgid, Adelgespiceae (Ratz.) (Hemipt., Adelgidae): A Hypothesis,” Applied Entomology, Vol. 99, No. 2, 1985, pp. 145-152.

[26] R. Bruck and W. P. Robarge, "Change in Forest Structure in the Boreal Montane Ecosystem of Mount Mitchell, North Carolina,” European Journal of Forest Pathology, Vol. 18, No. 6, 1988, pp. 357-366. http://dx.doi.org/10.1111/j.1439-0329.1988.tb00223.x

[27] T. A. Bowers, "Forest Structure and Health Trends in the Southern Appalachian Montane Spruce-Fir and Northern Hardwood Ecosystems of the Black Mountains, North Carolina,” North Carolina State University, Raleigh, 2005.

[28] H. S. Adams, S. L. Stephenson, T. J. Blasing and D. N.
Duvick, "Growth-Trend Declines of Spruce and Fir in Mid-Appalachian Subalpine Forests,” Environmental and Experimental Botany, Vol.25, No. 4, 1984, pp. 315-325.

[29] J. A. Witter and I. R. Ragenovich, "Regeneration of Fraser Fir at Mt. Mitchell, North Carolina, after Depredations by the Balsam Woolly Adelgid,” Forest Science, Vol. 32, No. 3, 1986, pp. 585-594.

[30] N. S. Nicholas, "Stand Structure, Growth, and Mortality in Southern Appalachian Spruce-Fir,” Virginia Polytechnic Institute and State University, Blacksburg, 1992.

[31] C. Eager, "Review of the Biology and Ecology of the Balsam Wolly Aphid in Southern Appalachian Spruce Fir Forests," In: P. White, Ed., The Southern Appalachian Spruce Fir Ecosystem: It's Biology and Threats, US National Park Service, Gatlinburg, 1984, pp. 36-50.

[32] G. F. Smith and N. S. Nicholas, "Size and Age Class Distributions of Fraser Fir Following Balasm Woolly Adelgid Infestation,” Canadian Journal of Forest Research, Vol. 30, No. 6, 2000, pp. 948-957. http://dx.doi.org/10.1139/x00-028

[33] R. T. Busing, "Red Spruce Dynamics in an Old Southern Appalachian Forest,” Journal of the Torrey Botanical Society, Vol. 131, No. 4, 2004, pp. 337-342.

[34] P. Soule, "Changing Climate, Atmospheric Composition, and Radial Tree Growth in a Spruce-Fir Ecosystem on Grandfather Mountain, North Carolina,” Natural Areas Journal, Vol. 31, No. 1, 2011, pp. 65-74. http://dx.doi.org/10.3375/043.031.0108

[35] U. Congress, "42 USC Chapter 85, Subchapter IV-A Acid Deposition Control,” US Federal Register, Washington DC, 1990.

[36] R. H. McManamay, L. M. Resler, J. B. Campbell and R. A. McManamay, "Assessing the Impacts of Balsam Woolly Adelgid (Adelgespicae Ratz.) and Anthropogenic Disturbance on the Stand Structure and Mortality of Fraser Fir [Abiesfraseri (Pursh) Poir.] in the Black Mountains, North Carolina," Castanea, Vol. 76, No. 1, 2011, pp. 1-19. http://dx.doi.org/10.2179/09-059.1

\author{
Abbreviation Key \\ LBA - Live Basal Area \\ DBA-Dead Basal Area \\ LSD_Live Stem Density \\ DSD_Dead Stem Density \\ BWA_Balsam Woolly Adelgid
}

\author{
VPI-Virginia Polytechnic Institute \\ DBH-Diameter at Breast Height \\ ABFR_Abiesfraseri (Fraser Fir) \\ PIRU_Picearubens (Red Spruce) \\ BEAL_Betula alleghaniensis (Yellow Birch)
}

